\title{
E- government and innovation in Italian Public Administration: A business approach
}

\author{
Ubaldo Comite \\ University of Calabria, 87036 Arcavacata of Rende (Cs), Italy \\ ubaldo.comite@libero.it
}

\begin{abstract}
E-Government consists of a strategic instrument for re-formulating the organization and the operation of Public Administrations, acting as a catalyst of trends and changes. It not only represents a resource that allows economic and operational advantages to be obtained, but is also an instrument that is capable of modifying the pre-existing operational mechanisms of the organization, guaranteeing a fast adaptation to continuous changes in the external environment.

The use of e-Government not only facilitates the internal activities of the Public Administration, but also has the advantage of facilitating the relationship between different administrations, as well as the interaction with citizens and with businesses.

The impact that e-Government can have is that of a better Public Administration, in that it allows public policies to be optimized, the quality of services to be raised, the involvement of the citizens to be widened, and other specific fundamental activities to be improved.

The present work intends to illustrate the comprehensive framework of the public administration system in Italy and of the main tendencies in progress, paying particular attention to the development of new management logic, considering e-Government not only as a merely technological phenomenon, but also analyzing it in its full meaning with regards to the process of change and modernization of the public administration.
\end{abstract}

\section{Indexing terms/Keywords}

Public Administration, E-government, Effectiveness, Accountability.

\section{Academic Discipline And Sub-Disciplines}

Business Administration, Management, Information Technology

\section{Council for Innovative Research}

Peer Review Research Publishing System

Journal: International Journal of Management \& Information Technology

Vol. 9, No. 2

editor@cirworld.com

www.cirworld.com, member.cirworld.com 


\section{INTRODUCTION}

During the last decade in the 20th century, the Italian public administration system entered into a phase of intense transformation and profound change. The development needs of the country-system ask, in fact, for competent and competitive Public Administrations, capable of implementing effective policies, able to better the quality of services offered and to create conditions for the development of the entire country. Public systems are, consequently, affected by the processes of modernization and innovation founded on administrative simplification, transparency, corporatization, and accountability, aimed at increasing the level of satisfaction in citizens and businesses with regard to the administrations themselves [1].

Even information technology has, in the last few years, contributed to giving further impetus to the process of Public Administration innovation. The road to modernization in the public sector is, furthermore, attributed to a set of circumstances that are interconnected with [2]:

- the complexity of contemporary society and the continuous quantitative and qualitative changes in the demands of public services by the citizens and the businesses present in the territory;

- the crisis of big government and the assertion in western countries of a new willingness oriented towards change in the public sector and the strengthening of the state through the rebalancing of accounts and the decentralization of functions, powers, competences and responsibilities;

- the operational crisis of the public sector, at the central as well as local level, in the direction of input, processes and output.

Input refers to the system of financing public shares, the increase, in many countries, of public expenses and public debts.

Processes concern the use of financial resources gathered for the production and distribution of public services. Within the processes are registered inefficiencies primarily traceable to the centralization of decision-making logics and to the lack of mechanisms for taking on responsibility oriented towards customer satisfaction.

Output concerns the quality of the public service and its ability of satisfying the actual needs of the end user, anticipating its needs.

This scenario has led a number of countries, including Italy, to implement, through e-Government, paths to reform aimed at revamping the image of the public sector, improving the performances of the singe administrations in terms of efficiency and effectiveness. The process involves single Public Administrations from a subjective point of view, and, from an objective point of view, the organizational dimension of the same [3].

Through e-Government, the intention is to increase the efficiency and the effectiveness of public actions (through a direct correlation between input, processes, and output and the reduction of administrative - bureaucratic constraints), to draw the single Public Administrations to the territory (for a smoother and quicker identification of the needs expressed by the citizens and businesses and more effective satisfaction of the same through a direct correlation between need, actions and result) and to introduce a model of external accountability within the single administration.

The use of e-Government within Public Administration can have the following impact [4]:

- the rationalization of internal management of single administrations through the streamlining of procedures, the rapid carrying out (in real time) of certain operations, the coordination among different operators;

- the modification of the system for the provision of service: the necessity of offering efficient, personalized and high quality services, for the both businesses and citizens, usable on-line without spatial and temporal constraints;

- the unification of information and services provided by different administrations;

- the improvement of communications with citizens and a greater transparency of administrative activities thanks to the large quantity of information that is easily accessible to all, maintaining, therefore, a process of increasing the trust of the citizens;

- strengthening the consensus formation process in the choices of the administration through the use of digital communication that will support the traditional institutions of representative democracy.

In any event, the impact that e-Government can have is that of a better Public Administration, as it allows public policies to be optimized, the quality of services to be raised, the involvement of the citizens to be widened, and other specific fundamental activities to be improved.

This approach makes it possible to identify two macro-areas of application - the increase of efficiency within the Public Administrations and the improvement of external relations, with all the sectors of society - together with the mid-to-long term goals that the process of e-Government should set.

The fulfillment of these strategies is part of a broader definition of the relationship between administrators and those administered, characterized by the need to change the mechanisms of participation in the democracy of a country, rendering the provision of public services to the community and to businesses on the whole more efficient - from the point of view of both quality and cost, allowing the use of the advantages linked to the emergence of a information society to the maximum number possible [5]. 
The reference to the dimensions along which e-Government is structured highlights the multiform nature of this phenomenon: e-Government can be considered a technological, organizational, managerial, informative, relational, and cultural phenomenon, but must be defined and studied as a result of all the aforementioned phenomena assembled in a system.

The observations explained above converge, in turn, into a declination of the subsidiarity principle ${ }^{1}$ [6], combined with that of a polyarchy [7].

This means that, thanks also to a well-balanced digitization, citizens and businesses are freer, and helped out ("subsidized" at a regional, national, and continental level) in carrying out the different activities and, at the same time, an effective measure of the impact of their actions on the country can be realized, through the observation of multiple players (polyarchy).

\section{THE PROCESS OF CORPORATIZATION OF PUBLIC ADMINISTRATION IN ITALY}

In the last few years, Europe has been the subject of important changes, registering rapid development on both the quantitative a qualitative level.

From a quantitative point of view, we have witnessed a rapid growth in size, going from a local viewpoint, the territory itself, to a continental viewpoint.

Simultaneously, the qualitative structure of the single market itself is being modified. In fact, the economic weight of individual countries has grown; these countries have intensified and improved the use of structural funds to increase strength and competitiveness by supporting the power of the Euro, an instrument of political, economic and social aggregation. The degree of complexity in the management of public administrations towards the changing needs of the administered community that compares and judges it has also developed.

The phenomena here mentioned have strongly involved Italian public administration which, furthermore, have found a further push and motivation in the orientation towards reviewing their management, organization, accounting, programming and checks system.

The advent of the European Union has brought the model adopted by Italian public administrations until now to an end, exposing the barely adequate level in performance standards, the excessive burden reached by the State deficit and the level of public debt, thereby imposing a radical re-thinking.

The reversal of trends has been demonstrated in various forms, all with a strong internal and external impact:

- the establishment of the intention to apply the theoretical, scientific principles and the techniques applied in businesses, in particular economy, efficiency and effectiveness and sound management to public administration;

- managerial change, geared towards the implementation of programming functions, senior management and control;

- the trend towards the reduction of public expenses to better the level of deficit and debt;

- the push towards an open, participatory, responsible public system aimed at accountability;

- the increasingly frequent use of modern Information and Communication Technologies (ICT), tied to electronic and internet development, aimed at the creation of a digitalized management system of public administration, which together with actions of organizational change - allows the documentation to be handled and the procedures to be managed with computer systems, in order to optimize the work of the government bodies and offer the users (citizens and businesses) rapider services as well as new services, though, for example, the web sites of the relevant administrations (e-Government).

All this can be encompassed by the term corporatization of public administration.

The prevailing business model is that of stakeholder oriented, in which the business is conceived of as in the centre of a network of interests in which the potential benefactors are the various subjects that characterize the administrative interests: the citizens, other public administrations, the suppliers of goods and services, the financiers, the employees and interest groups.

In this context, public administrations, in order to proceed without interruption and with consistent actions, must work towards guaranteeing simultaneous satisfaction to different interests. A similar competition can be reached with a midto-long term period viewpoint that presumes conditions of efficiency and economy that establish the creation and equitable redistribution of wealth as the goal to maximize, in favour of a wider circle of participants. All of this has led to paying precise attention to the performance of factors used with the reduction of funds for the activities unable to

\footnotetext{
${ }^{1}$ The term "subsidiarity" is derived from the Latin word subsidium, that indicates reserve troops; the Roman military terminology, in fact, distinguishes cohorts fighting on the frontline (in the prima acies) from reserve cohorts, who stand ready behind the frontline (the subsidiariae cohortes). Subsidiarity, when applied to society, indicates the compensatory intervention and support of the biggest social entities - mainly from the State and from organized utilitarian institutions - in favor of individuals and smaller social groups. The principle of subsidiarity assumes solidarity and the common good, but does not identify with them. That society should help the individual is a clear affirmation of the principle of solidarity, which underlines the ties and mutual obligations between them, but it is the principle of subsidiarity, which divides, defines and specifies the expertise that are to be respected in a similar intervention.
} 
generate wealth at an adequate level (often previously based on evaluation that lacked a foundation of economy), or rather the raising of the interest threshold on revenue in respects to what was practiced before.

At the same time, the number and importance of local authorities - regional, provincial and municipal- operating with more direct contact with potential benefactors has increased.

Another factor that contributed to modifying the logic and modes of operation of the public administration was the principle of distinction between the political sphere and the managerial sphere and, particularly, between guidance and monitoring activities and that of management, pursued for some time, in various European countries, as well as in the community ordinance. This regulatory provision has had the effect of intensifying the frequency of manager and/or employee involvement in operations management. This instrument, which aims, among other things, to promote the diligence and the efficiency of those who, in different ways, participate in public administration affairs, inserting a new point of view into the sector that contributes to redefining the relationship system between public administration and the community administered [8].

Consequently, the transition to a new public administration is characterized by its strong orientation towards economy, aimed at a sound management of limited resources in order to maximize the creation of economic-social value, or rather, public value.

The abovementioned phenomena are essentially ascribed to the following factors:

- the increasingly marked tendency towards "Europeanization" as a response to the globalization of the economy;

- the progressive de-regulation and increase of de-centralization in favour of local authorities

- the emergence of the phenomenon of communication and economic, social and environmental information;

- the expansion of e-Government as a means of administration exercised with technological instruments. With specific reference to e-Government, the application of new technology in the public sector has had the following impact:

- the rationalization of internal management of single administrations through the streamlining of procedures, the rapid carrying out (in real time) of certain operations, the coordination among different operators;

- the modification of the system for the provision of service: the necessity of offering efficient, personalized and high quality services, for the both businesses and citizens, usable on-line without spatial and temporal constraints;

- the unification of information and services provided by different administrations with the advantage that the constituency ${ }^{2}$ will turn to any front office administration;

- the improvement of communications with citizens and a greater transparency of administrative activities thanks to the large quantity of information that is easily accessible to all, maintaining, therefore, a process of reducing corruption and increasing the trust of the citizens;

- strengthening the consensus formation process in the choices of the administration through the use of digital communication channels that act as support for the traditional institutions of representative democracy.

\section{THE PROCESS OF E-GOVERNMENT IN PUBLIC ADMINISTRATION: FROM E- GOVERNMENT TO E-GOVERNANCE}

There are many definitions of e-Government, and term is not used univocally, and may have different meanings.

The differences are not only semantic, and reflect the strategies that each government implements.

It is possible to divide the definitions into three groups:

- e-Government defined as the provision of services via the internet (on-line) as well as other activities based on the internet such as e-consultation;

- e-Government equated to the use of ICT in the administration. While attention is usually given to the provision of services and on its operations, this wider definition covers all aspects of administrative activities;

- e-Government defined as the ability to transform Public Administration through the use of ICT, or rather, as an expression used to describe a new form of administration constructed around ICT. This aspect is usually connected to the use of the internet.

The terms and definitions evolve to changing priorities, as it is a dynamic field that is rapidly evolving.

The definition that is closest to the etymology to the Anglo-Saxon word "e-Government" is that which identifies eGovernment together with the processes and operational structures for electronic distribution, on the part of public administration agencies, of information and services to citizens, businesses and other public administrations [9].

The OECD defines e-Government as the use of new information and communications technologies, particularly the internet, as instruments for the improvement of public administration [10].

\footnotetext{
${ }^{2}$ Constituency intents the citizens, the businesses and all the social and economic participants the interact with public administration.
} 
Electronic government is defined in literature as the process of transforming internal and external public administration relationships through network activity, information technology and communication in order to: 1) optimize the distribution of services; 2) increase citizen and businesses participation; 3) improve the ability govern [11] [12] [13] [14].

Part of the doctrine has embraced an interpretation of e-Government in a broad sense, arguing that it can be understood as a "vision" which implies [15] [16]:

a) the modernization of the administrative machine;

b) the re-engineering of the processes in order to allow access to services through innovative technologies;

c) the provision of services that provides for and enables the active and intense involvement of the citizens in the democratic process;

d) the technical integration and the interconnection of organizations and between organizations and citizens.

In other words, a broad view of e-Government means that the same arises as a widespread concept that operates on five elements [17]:

1) the new modality of citizen participation (e-Democracy);

2) the modality of service production of the public administration and the necessary and consequent reorganization of processes;

3) the modality for the provision of services with innovative modalities;

4) technological infrastructure;

5) organizational infrastructure.

The first three represent the main areas of e-Government intervention, namely those in which value or non-value is prevalently generated; the other two represent infrastructural and support areas to all the previous ones. In their absence, and in particular without technological infrastructure, there is no e-Government.

Holmes defines the process of e-Government as the use of information technology, in particular the internet, for the distribution of public services in a manner that is different, more convenient, oriented towards the client and is more effective. It influences the relationship between the public administration and the citizen, businesses and in general all the public administrations, as indeed it influences civil servants. The process of e-Government began as guided by the needs of the Government to: cut costs and increase efficiency; meet the needs of the citizens and boost relationships with them; facilitate economic development [18].

Other definitions also imply a fairly wide concept of electronic government, seen not only as an evolution of the activities tied to public administration, but as more general transformations of the State, through a thorough reexamination of the practices and democratic progress.

Zulfiqar and Shan sustain that the process of e-Government implies a complex and dynamic transformation of the entire state apparatus, at each level, that takes advantage of ICT to involve the sharing of information and citizen, business, administration, government and civil servant public administration strategies [19].

Stiglitz et al. state that with a knowledge- based approach, the success of an e-Government plan depends above all on the full participation in the processes of all the stakeholders involved, allowing not only for a strong infrastructural and conceptual evolution of the administrative apparatus to be obtained, but also for the alteration of the manners in which appropriate rights and duties are exercised [20].

Devadoss, Pan and Huang deal with the theme of e-Government by looking at social and organizational factors that play a role in the development and implementation phases, according to the perspective of structurational analysis [21].

Zulfiqar, Pan, Lee and Huang examine the theme of e-Government in light of three factors: technological challenges, user preferences and institutional layout [22].

Bombardelli defines e-Government as the use of information and communication technology and used in substitution of traditional instruments in government actions and administrative activity, in order to optimize, through an improved circulation of information, the relationships external to the administrative apparatus and to improve through greater speed and flexibility their organization offered to the citizen [23].

Pollifroni speaks interchangeably of e-Government and e-Administration as the use of modern information and communication technology tied to the development of electronics and the internet, during the modernization process of the public administration [24].

In light of the above, we can assume that the use of ICT in the realization process of electronic government presupposes that, on the one hand, new technology contributes to an improvement of the internal efficiency of public administration, allowing for an increase in the efficiency in the management of information and administrative processes, with consequences on the relationship between the administrative apparatus, at a horizontal level (agencies, departments and ministers) and at a vertical level (central and local administrations) and on the other hand, 
ICT allows for an improved position in the management of external relationships - that is, the constituency guaranteeing higher standards in the provision of services and information to public, as well as - potentially - a rate of democratic participation at a level up to now unthinkable.

Using ICT in a public administration means:

producing more efficient and personalized services, for the both businesses and citizens, usable without spatial and temporal constraints

improving communications with citizens, making administrative activities more transparent, thanks to a large quantity of information that is easily accessible to all, with positive effects in terms of the fight against corruption;

allowing citizens and businesses to actively participate in public decision-making processes through the use of communication channels that will support traditional institutions of representative democracy.

Naturally, these objectives necessitate, other than widespread sharing, a realization of a series of preliminary acts, or rather:

the implementation of policies aimed at facilitating access to information and public services (tax policies for the spread of telematic instruments, training policies, provision of infrastructure, planning of services in a multimedia viewpoint) so as to minimize the phenomenon of excluding potential users present in a country (digital divide);

the re-organization and re-thinking of structures within the public administration, from a viewpoint based on the satisfaction of user needs.

E-Government is, in fact, a program, a strategy; it is not a technological endeavor, but a strategic design based on three essential elements: 1) human capital; 2) technology; 3) organization.

Currently, the emerging models of e-Government are:

G2C - Government to Citizen: consists of the activity of providing services on the part of a public administration to its citizens (also included in this model are, for example, the creation of public administration web portals, online services, call-centres, etc.);

G2B - Government to Business: includes the activity of providing services on-line on the part of a public administration to businesses (also included in this model, are, for example, forms presented in electronic format for taxes, social security, insurance etc.);

G2E - Government to Employees: consists of the activities tied to the provision of services on the part of a public administration to its employees (also included in this model are, for example, training activities for personnel through e-learning);

G2G - Government to Government: included in this model are, for example: a) collaboration activities between public administrations belonging to the same State (an example in Italy comes from the implementation of a National Public Administration Network); b) collaboration initiatives between the public administrations belonging to different States, aimed at combating international organized crime (counter-terrorism intelligence activities, the drug and arms trade, etc. ), international cooperation for the development of weaker countries, research, etc.;

B2G - Business to Government: covers the activities of electronic commerce tied to the supply of goods and services on the part of businesses to public administrations (included in this model are, for example, activities of e-public procurement).

The use of technology is changing administration, namely, the manner of relating between those responsible at different government levels, and even the relationships amongst the citizens and businesses. Through the instruments of e-Government, the circulation and exchange of a multiplicity of data and information is achieved; utilizing these it is possible to provide services and carry out administrative procedures in a digital manner. This transforms the traditional operational mechanisms of the administrative apparatus and potentially transforms all the institutions in organizational networks and all the organizations in core elementary networks.

It is necessary to highlight that the detailed technological connotations of e-Government directly affect the relationships between various administrations. The possibility of data exchange and provision of services carried out in automatic modes calls for the sharing of operational methodologies.

The expression e-Governance can be added to the concept of e-Government; it is meant to refer to the application of the instruments of an information society to the models of state intervention, in the context of participation and transparency in public management decisions. It is an organizational model of the policies achieved through mechanisms of negotiation.

e-Governance represents, therefore, a set of possibilities made possible by new means of communication, by the direct participations of citizens in the development of political decisions in the democratic life of a country, or a community, offering greater transparency in relationships.

The common denominator between the processes of e-Governance and e-Government is represented by the use of modern ICT technology; differentiating aspects are, instead, identifiable in the following objectives: 
1) e-Governance seeks to improve the democratic process of a country, or a community, by attaining greater transparency in government activities;

2) e-Government seeks, instead, to optimize the organization and operation of public administrations.

The models of governance ${ }^{3}$ [25] that are spreading in Italy are transforming the public decision-making system, and in particular the decision-making system of public administrations, from a process in which regulations, procedures and behaviour are imposed from above through instruments of various coercive ranks, into a process in which principles of participation, responsibility, effectiveness and consistency are concretely applied.

In this context, governance is directed towards various decision-making levels within a public organization, which is no longer structured as a pyramid, with state bureaucracy authorities at the vertex, but oriented horizontally with the participation of a variety of bodies in the decision-making processes, and with constitutional autonomy such as regions, provinces, municipalities, in that particular structure ordinarily better known as federalism.

The evolution of the regulatory framework in regarding e-Government must be considered within an institutional system that consists increasingly of multiple levels of government [26].

As also observed by the doctrine, the subject of e-Government cannot be limited to only information technology coordination, in that through the use of information and communication technologies, good government of public administrations and the democratic development of society and economy is pursued [27].

The technological choice not only affect the coordination of data, but also impact the organizational aspects of public administration, a matter that the Italian Constitution entrusts to the regional legislative competences and to the administrative competences of the local authorities and same regions [28].

Today, therefore, it is asked even of the administrations to evolve quickly towards a logic of governance, bearing in mind the diversity of those interested in adopting policies, guidelines, and choice that are able to converge needs towards mutually acceptable solutions.

To summarize, the logic of governance can refer to the operations within the administration (participatory organizational model), the relationship between different authorities/public administrations (public system governance), as well as the relationship with external subjects, especially businesses and social forces (global governance system via planned and/or negotiated programming) [29].

Public administrations must, therefore, structure governance systems, in order to both plan and monitor the economicfinancial trend, thereby improving general efficiency, as well as to promote a constant and continuous process of selfimprovement in management and to verify appropriate activities and the achievement of predefined objectives in respects to the principles of:

- economy and efficiency;

- responsibility and indivisibility of the administration;

- homogeneity of the functions and sectors of intervention;

- adequacy in ensuring the exercise of the function;

-dissemination of information technology instruments.

\section{The different levels of e-Government}

The process of e-Government development passes through different stages.

In the doctrine, there are those who have noted the existence of three levels, those who have hypothesized four, five or even six.

In particular, Howard [30] has distinguished three stages in the development of e-Government:

a) publication: public administration limits itself to supplying information on its aims and activities;

b) interaction: public administration offers the citizen the possibility of a easy interaction, such as sending e-mails or participating in group discussions;

c) transactions: the public administration allows the citizen to initialize veritable transactions aimed at, for example, the purchase of licenses, permits, etc.

The model proposed by Howard overlooks the important integration phase between the different structures of public administration. This stage is variously proposed by those who propose developmental models of e-Government in four, five, or six stages.

\footnotetext{
${ }^{3}$ For a clear conceptualization of governance, it is possible to refer to the United Nations Development Program (UNDP, a subsidiary body of the UN), that defines governance as "(...) the exercise of political and administrative authority at all levels to manage a country's affairs. Governance comprises the complex mechanisms, processes and institutions, through which citizens and groups articulate their interests, mediate their differences, exercise their legal rights and meet their obligations $(. .$.$) . Governance includes the$ State, but transcends it by including the private sector and civil society (...)".
} 
Layne and Lee [31], in distinguishing the four phases of:

a) cataloguing, in which the public administration is limited to a minimal on-line presence and to providing information;

b) transaction, in which the citizen is enabled to interact with the public administration;

c) vertical integration, in which the public administration provides for the integration between its database and that of the public administration above hierarchically .

d) horizontal integration, in which the public administration provides for the integration between different services, allowing for real on-line "purchases";

notably focus their attention on this phase, even hypothesizing a double level of action within it.

On the contrary, Chandler and Emanuels [32] hypothesize of four levels, distinguishing the levels of mere electronic information, interaction, transaction and integration.

Those who recognize more levels essentially divide each of the abovementioned phases into sub-phases.

A study carried out by the United Nations, for example, calls for five phases, adding the regular updating of the website to the information phase [33].

In any event, from what emerges from the analysis of the literature on the models of e-Government development, it seems possible to conclude that [34]:

a) there is no agreement on the number of stages that characterize the evolution of the e-Government system;

b) even if the first level has been defined in different manners, all agree upon its goal, consisting of rendering information available on-line without the possibility of interaction;

c) in general, the fact that that purpose of integration is to render the services of public administration available in a unified manner from a single access point is agreed upon;

d) all the models mention a transaction stage, and in almost all the models, it is presented as a central level.

This last aspect underlines the importance of this stage, which is, in fact, presented as fundamental for the improvement of effectiveness in the implementation of the e-Government process. Only through the full realization of this level, in fact, do the citizens have the full possibility of carrying out complete transactions with the public administration, reaching a point of being able to pay on-line securely. In this manner, not only does the satisfaction of the users increase, it also generates a saving of both time and money at both the general systematic level and in the individual public administration.

\section{THE EUROPEAN AND NATIONAL PANORAMA}

The process of technological innovation launched by the Italian public administration is inspired by development strategies shared at a national and international level, whose roots can be found in the strategic framework outlined by the member countries of the European Union who met in Lisbon in 2000, where the objective of "becoming an economy based on the most competitive and dynamic knowledge in the world " was set [35].

The implementation of this objective was initially broken down in the eEurope 2002, eEurope 2005, i2010 initiatives, and today with the European e-Government Action Plan 2011-2015.

In particular, the eEurope 2002 action plan aimed primarily at the spreading internet connectivity, while the eEurope 2005 plan worked at increasing economic productivity and improving the quality and accessibility of public administration services.

The i2010 action plan was instead directed towards promoting an open and competitive digital economy, emphasizing ICT technologies as a fundamental instrument for the inclusion (or rather, the integration and accessibility of service for all user groups, whether they be urban or rural residents) and the quality of life.

The European e-Government Action Plan 2011-2015 is part of the digital agenda 2020 and intends to make use of information and communication technologies (ICT) in order to improve the effectiveness and the dynamism of European administration ${ }^{4}$.

The new strategy requires the Member States and the EU to face the main obstacles in an "intelligent, sustainable and inclusive" growth, particularly in regard to the internal market, infrastructure, research and employment but also education, social cohesion and climate change.

\footnotetext{
${ }^{4}$ The Digital Agenda for Europe 2010-2020 is the new ten-year program document that takes over from the i2010 e-Government Action Plan. It establishes, within the different measures for the growth and diffusion of ICT, a strategic role in the interoperability between systems. The Digital Agenda advances from the European Union Strategy 2020, which identifies, as a priority for Europe over the next ten years, a growth that is: a) smarter, promoting knowledge, innovation, education, and digital society: b) sustainable, making production more efficient under the profile of resource use, and the same time re-launching competitiveness; c) inclusive promoting participation in the world of work, the acquisition of skills and the fight against poverty. The Digital Agenda, lies, therefore, between the various measures for achieving the priority objectives of the 2020 Strategy.
} 
The Member States are called upon by the European Council to develop programs and objectives consistent with the new strategy, both through the National Reform Plan submitted to the Commission in November 2010 and through the participation of individual actions launched at an EU level.

The overall objective of the action plan is to facilitate the transition from the current e-Government towards a new generation of digital administration services at a local, regional, national and European level.

To reach this objective, four types of action to undertake have been identified.

Priority 1: empowering the users.

Empowering the users aims at increasing the abilities of the citizen, businesses and other organizations to be proactive in society, through the use of new technological instruments.

Priority 2: strengthening the internal market.

Currently, using the services from one country to the other within the EU is complicated. To strengthen the internal market on this level, the European Commission proposes different initiatives for development: 1) services without continuity solutions for businesses; 2) personal mobility; 3) carrying out transnational services at the EU level.

Priority 3: improving the efficiency and effectiveness of administrations.

To improve the efficiency and effectiveness of the administrations, the present action plan emphasizes the need to highlight information and communication technologies (ICT), enabling the 1) improvement of organizational processes; 2) reduction of administrative obligations; 3) prioritizing the green public administration.

Priority 4: creating the prerequisites for the development of e-Government.

The implementation of e-Government services in Europe requires the establishment of a series of conditions, among which are: 1) interoperability; 2) identification and authentication; 3) innovation.

In Italy, the backbone in terms of policy directives for the development of ICT in public administrations is undoubtedly represented by the strong link set by the Italian Government between the productivity of public works, and the efficiency and transparency of public administrations on the one hand, and ICT innovation on the other.

A method has been proposed for the development of ICT through:

- multilevel memoranda of understanding, which involve central public administrations, and Regional and Local Authorities;

- infrastructure programs, among which the Public Connectivity System ${ }^{5}$ (SPC) in all its component parts (connectivity, security, basic interoperability, advanced interoperability, applicative co-operation);

-innovation of the legislation with reference to the Digital Administration Code.

This operability has lately resulted in the drawing up of the three-year plan 2012-2014 by the Ente Nazionale per la Digitalizzazione della Pubblica Amministrazione (National Agency for the Digitization of Public Administrations) (DigitPA) ${ }^{6}$

The plan firstly aims at highlighting the strategic and unique role, from an Italian outlook, of DigitPA (now the Agency for a Digital Italy). The strategy and uniqueness derive from the proposal of a complete reading of the four

\footnotetext{
${ }^{5}$ The Public Connectivity System (Sistema Pubblico di Connettività - SPC) is a set of infrastructure technology rules and techniques that aims to "federate" the ICT infrastructure of the public administration with the purpose of achieving integrated services through shared rules and services. This integration allows money and time to be saved, and achieves the final user-centred services, avoiding repeated requests for data from administrations, as well as the duplication of information and checks. The Digital Administration Code (Codice dell'Amministrazione Digitale - CAD) defines it as: "the set of infrastructure technology rules and techniques for developing, sharing, the integration and dissemination of information assets and government data, necessary to ensure basic and evolved interoperability and applied cooperation of information systems and the flow of information, ensuring security and the confidentiality of information, as well as the preservation and autonomy of information assets of each public administration." Within its set of technical rules and principles, the Public Connectivity System is therefore a national interoperability "framework": it defines, that is, the preferential mode that the information systems of public administration must adopt to be "interoperable" amongst themselves. The aspects of interoperability are ensured by rules, and above all, by a series of interoperability, cooperation and access services that are part of the national shared PCS infrastructure. The Public Connectivity System defines, furthermore, both the enterprise architecture of the Italian public administration (or rather, the reference system necessary to link the inter-administrative operational processes with the information systems that support them), as well as subsidiary, coordination and governance actions.

${ }^{6}$ DigitPA National Agency for the Digitization of Public Administration, in accordance with art.3, comma 1 of the Legislative Decree 1 December $2009 \mathrm{n}^{\circ} 177$, is a non-economic public body, based in Rome, with expertise in the field of information and communication technology in public administration. It operates according to the guidelines for the implementation of policies and under the supervision of the Prime Minister or the Deputy Minister, with technical and functional, administrative, accounting, financial and asset autonomy. DigitPA carries out planning, technical and operational functions, with the mission to contribute to the creation of value for citizens and businesses on behalf of the public administration, through the creation of digital administration. Its aims can be summed up as giving value to citizens and businesses through effective and efficient public administration through informed, shared and sustainable use of information and communication technology. With Decree Law 22 June $2012 \mathrm{n}^{\circ} 83$ DigitPA, the Agency for the Diffusion of Technology for Innovation, the Department of the Premiership for the Digitization of Public Administration, and the Institute of Communication and Information Technology were incorporated into the Agency for Digital Italy.
} 
fundamental functions of DigitPA.

The first function: DigitPA is called to consult and propose on the issues of intervention for the construction of the Digital Administration, primarily referring to, for the three-year period in question, the e-Gov 2012 Italian plan.

The second function: the need to emit guidelines, technical rules and standards to verify the feasibility of the solutions proposed.

The third function: the achievement of innovation, development and ICT research projects, even in a public-private partnership (drawn from funds of a diverse nature, frequently national, but also international).

The fourth function: assessment, monitoring and coordination of the various ICT initiatives that the individual public administrations intend to take on.

DigitPA therefore plays the role, comprehensibly, of a mix of regulations (first, second and fourth functions) and of project actuator (third function).

The digitization of Italy represents an element of cultural and economic development, of a historic significance, undoubtedly comparable to the laying, in the past, of the Italian railroad network, the electric and national telephone lines, to television and highways.

It constitutes, on the one hand, an indispensible element to achieve federalism in concrete terms, and, on the other hand, necessary factors for the interconnection as provided for by the Digital Agenda for Europe, and, more generally, an enabling technological factor for a constructive dialogue with all the countries in the world, especially in order to spread the values of culture and Italian labour (Made in Italy).

To summarize, with specific reference to the reality of Italian public administrations, the new scenarios that are opening up can lead to important innovations in administrative and government methods.

Specifically, it can be said that the recourse to e-Government can impact the following profiles:

- benefits are generated in the carrying out of administrative procedures, managerial processes and in internal communication creating advantages in back-office activities;

- the centrality of information for decision-making is affirmed, and the operations of systems oriented towards the search of efficiency and effectiveness are enhanced, particularly supporting the activities of programming and control;

- from an organizational point of view, solutions that focus on processes are solicited and made more viable. These processes, based on their potential seem, at least theoretically, particularly in accordance with the productive/distributive characteristics common in public corporations;

- the quali-quantitative development of information assets contributes to enriching the intellectual capital available and favouring the implementation of models inspired by knowledge management;

- the reengineering of service production processes ${ }^{7}$ for the community and the expansion of relative channels of fruition, contributing to raising the level of user satisfaction and to bettering the interpretation of the new role of "regulator" that public corporations today must take on in the field of public service is favoured;

- notable effects in terms of transparency, accessibility, inclusion and participation in favour of the citizen can be produced, placing the citizen centrally in respects to political choices and public administration operations. The effects that the use of the internet and other technologies have on so-called front-office activities is evident.

\footnotetext{
${ }^{7}$ Business Process Reengineering (BPR) is a business management strategy of thorough revision of the operative procedures that are no longer adequate for the needs of the business. Process refers to a set of interconnected activities that lead to final results that the client can identify, that therefore contribute to valuable training for the business. The incentive for intervention may come from benchmarking results, customer satisfaction analysis, variation of the operative framework, the redefinition of business objectives, other critical parameters that point out the necessity or opportunity to improve the effectiveness and efficiency of a business process, the necessity of introducing new work methods or other situations. A reengineering intervention provides, as usual, the analysis of the existing situation with a mapping of the primary process and the support processes, identification of critical and susceptible points open to improvement, the study of solutions and the consequent reengineering of the process in a coherent way. In the analysis, total quality techniques can be used, with particular attention to the necessity of being able to measure the parameters that indicate the benefits of the process. The processes transverse the business functions, and very often it is right where the various functions cross that the main points of inefficiency or lack of coordination emerge. Reengineering is basically a radical thorough redesigning, even starting again from scratch, and not a simple improvisation or adjustment or improvement to operability. Often, reengineering also aims at having a more streamlined and elastic structure, and is specifically targeted to the processes that are crucial to the business, namely those that have a significant impact on the final product. The reengineering of the process makes use of the usual instruments of organizational interventions, such as: the redefinition of hierarchies, of organizational levels and of the decision-making chain; the modification of the roles assigned to positions; the unification, the division or making the activities or functions parallel; the elimination of activities with no added value; the acquisition of new work instruments; the use of new methods or of new technologies with the ensuing training plans; the adjustment of workspace; the identification of appropriate incentive systems; the adoption of new information systems; the reengineering of software systems that support correlated information systems; the removal of obstacles that condition the process, and so on, going on to normally affect various business functions. If the reengineering is carried out as a fast response to a market change, it can give the company a competitive advantage over time in respects to other companies. It should be pointed out, though, that real reengineering requires a complete change to the current operational mode, and that it is normally therefore a long-term, high risk, high cost activity which necessitates the staunch involvement of the entire business. For this reason, improvement operations that are less traumatic are often opted for, even if the results are lesser.
} 
- There are important solicitations for greater integration and co-operation in the public administration system, and in the same with the private and nonprofit sectors.

Through the recourse to e-Government, public administration is transformed into a horizontal grid system capable of communicating and interacting with itself and with external users [36].

\section{The evolution of the national regulatory framework}

The regulatory framework within which to analyze aspects related to benefits, including economic, arising from the introduction of new technologies in the Italian public administration, contributes to some important regulations, recently introduced into Italian law:

1) Law n. 133/2008 [37] (Budget Law 2009) which introduces the concept of performance in public administrations and the efficiency dividend for public administrations;

2) the Directive of 26 November $2009 n^{\circ} 8$ of the Ministry for Public Administration and Innovation governing the "Guidelines for public administration websites", concerning the orientation criteria and the instruments used for the processing of data, their public documentation and traceability;

3) Law n. 196/2009 [38], referring to the audit of the State Accounts. This law, aimed at strengthening the mechanisms and instruments for the quantitative and qualitative control of expenses, by adopting a greater orientation towards the measurement and assessment of the results, stabilizes a new presentation layout of the State Budget, based on a classification of missions and programs, therefore from a full-cost perspective, in respects to the traditional structure based on items and expenses;

4) Legislative Decree n. 150/2009 [39], which indicates the procedures for allocating reward schemes for administrative personnel;

5) Legislative Decree. n. 82/2005 [40], as modified by Legislative Decree n. 235/2010 [41], which imposes upon the administrations to quantify the savings introduced by technological innovations;

6) CIVIT $^{8}$ Deliberation $n^{\circ} 105$ of 2010 , concerning the access by the entire community to all public information, according to the freedom of information paradigm of open government, which originated in the United States of America.

Together, these regulations ensure that an administration, after having re-classified its budget for cost/productionservice centres, can calculate savings resulting from lower costs due to an increase in efficiency, thanks to the use of ICT, and productive processes of specific products-services.

These savings generate an efficiency dividend that can be re-distributed as a reward scheme, in accordance with Legislative Decree n. 150/2009, to the employees in the administration that collaborated towards an innovative improvement of the service, thanks to the introduction of the concept of performance, in turn measurable thanks to the concept of full-cost.

In this frame work, DigitPA is called up to play a central role as accompaniment and consultancy to the administrations in the use of ICT for the improvement of administrative processes (Figure 1).

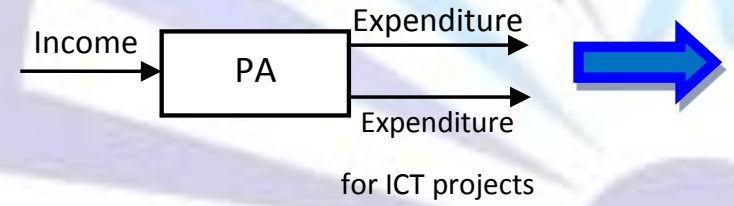

Situation before Lgs.D 10/2009 and

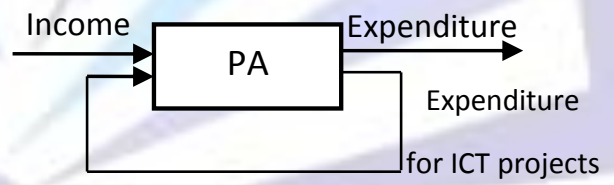

Situation after Lgs.D 10/2009 and

Lgs.D 235/2010 accounting reforms

Fig. 1. The different role of investments in ICT when the system goes from an open chain to a closed chain (Source: personal elaboration)

\footnotetext{
${ }^{8}$ CIVIT (now ANAC) is the Commission for the Evaluation, Transparency and Integrity of public administrations. It is an independent autonomous authority, established by legislative decree 27 October 2009, n. 150. Its fundamental purpose is to guarantee, in a manner independent of the government, the optimization of the productivity of public work and the efficiency and transparency of public administrations. The law entrusts the Commission, called upon to operate in a position independent of judgment and evaluation and in full autonomy, with the task of addressing, coordinating and supervising the functions of evaluation, guaranteeing the transparency of the systems adopted and the visibility of the indices of public administrations management trends. This task which is essentially geared towards promoting the efficiency of public activities and the quality of services provided to the citizens, even recognizing and for all intents and purposes, awarding the merit of individuals and groups that operate within the administrations- is accompanied by the task of guaranteeing total transparency of the administrations, namely the accessibility of the data relevant to their use even with a supply network of an astute selection of those which are truly useful to allow institutions and citizens to operate participatory control on the modalities of public administration management. This function is also particularly important, because, as intended by the legislator, the transparency of data must constitute an instrument in ensuring the integrity of public administrations, and thus preventing the serious phenomenon of corruption.
} 


\section{FINAL CONSIDERATIONS}

The evolution of information systems asks for and entails an important impact at an organizational level, in particular [42]:

- A re-organization of the internal management modes of the authorities, with the introduction of a logic for processes in place of the one for organizational units;

- the transparency and integration of the business data assets, as opposed to the previous fragmentation and sectoring of information;

- the loss of the traditional territorial characteristic of public administration, which removes the physical boundaries of the authority and pushes towards the virtualization of services, the relationship with the citizen and the reference community.

What is asked from the public administration is not a simple internal re-distribution of responsibility as much as the adoption of new operational logics, inserted into daily activity, which take into account the availability and potential of new instruments.

From this perspective, the possible evolution of the changes generated by the computerization of the public administration in Italy can be described:

- the traditional organizational boundaries of public administration are reconfigured into a dimension of the network: a) on the territory, with the other administrations and private organizations; b) in respects to other levels of government, with the consequent simplification of interactions and the redefinition of the attributes traditionally entrusted to the bodies of coordination;

- the information systems of the organization are opened to external users;

- the increasing need to address, in a systematic manner, the management of the rapidly growing quantity of information, and the greater awareness of the potential of the information as a strategic value in the enterprise and government sector. This is drawing considerable investments into solutions of document and content management, up to more sophisticated forms of information retrieval, automatic language processing and knowledge management. The public sector, which has information and document management as its core business, is one of its main fields of ideal application of these technologies;

- the spread of systems and services for social collaboration in the consumer market is raising the perception that these systems can be introduced successfully even in businesses and the public sector. The public administration, seen as a large federated enterprise, capable of carrying out complex relational and reticulate forms of collaboration and partnership, is a promising field of application.

Until public communication can be considered truly effective and coherent with institutional aims, all citizens must continually have the concrete possibility of using information technology means regardless of economic conditions, social status, age and residence.

If it were not like this, a preventative selection of the demand would be created, which would even end up limiting the opportunities for investment carried out by the public administration (the so-called digital divide).

It can, therefore, be concluded that the purpose of the internal re-organization of public administrations must, in fact, be that of demonstrating the public administration to the citizens as a single homogenous entity, with which to interact through a virtually unified on-line access point, regardless of any geographical, organizational, or accessibility constraints.

In this manner, the onus of knowledge and adaption to needs moves from the citizen - who should know the structure within the public administration, in order to understand which authorities provide the service needed and how responsibilities are divided amongst themselves - to the administration, which, on the base of the citizen needs, organizes an appropriate back-office and suitable services to be offered.

The success of e-Government initiatives appears, therefore, linked to the ability to organize the innovative services offered on -line based on the needs of the citizens, and to choosing instruments and methods of distribution that adapt to the necessities and peculiarities of all possible users as much as possible.

In this sense, ICT undoubtedly constitutes an important stimulus to the spread between and in the public realm of a way of thinking and operating in a managerial matrix so much so as to speak of a Public Management Information System and, as some suggest, of e-Public Management [43].

This entails a clear drive towards a less fragmented concept of management and towards a smaller gap between political circumstances and managerial and administrative circumstances.

ICT and e-Government represent, therefore, a great opportunity for the development and promotion of true corporate culture.

\section{REFERENCES}

[1] Anselmi, L. 2003. Percorsi aziendali per le pubbliche amministrazioni, Giappichelli, Torino. 
[2] Borgonovi, E. 2002. Le tecnologie dell'informazione e il cambiamento dell'amministrazione pubblica, Azienda Pubblica ${ }^{\circ} 5$, Maggioli, Rimini.

[3] Pollifroni, M. 2003. Processi e modelli di e-government ed e-governance applicati all'azienda pubblica, Giuffrè, Milano.

[4] Capocchi, A. 2003. Il processo di e-government nel sistema delle amministrazioni pubbliche, Giuffrè, Milano.

[5] Hinna L. and Monteduro F. 2006. Amministrazioni pubbliche. Evoluzione e sistemi di gestione, Aracne, Roma.

[6] Comite, U., 2009, Creazione di valore e sussidiarietà nell'amministrazione pubblica. Un approccio economico aziendale, in Calabrò G.P. (ed.), La nozione di sussidiarietà tra teoria e prassi, E.S.I., Napoli.

[7] The term polyarchy is derived from the Greek words polys (many), more than one, and arkhé (command), and means therefore the command of many.

[8] Jannelli, R. 2007. Governance e misurazione delle performance nell'azienda pubblica. Un possibile approccio, Aracne, Roma.

[9] Okotuma W'OR, Electronic Governance: Reinventing Good Governance, available at http://www1.worldbank.org/publicsector/egov/Okot-uma.pdf, $n^{\circ} 8$

[10] OECD, 2003. Implementing e-Government in OECD countries, experiences and challenges, Background paper.

[11] Kooiman J. and Van Vliet M. 1993. Governance and public management, in Eljassen K.A., Kooiman J, Managing public organizations: lessons from contemporary European experience, London, Sage.

[12] Meneguzzo, M. 1997. Ripensare la modernizzazione amministrativa ed il New Public Management, Azienda Pubblica, Maggioli, Rimini, $n^{\circ} 6$.

[13] Meneguzzo, M. 2005. Creazione di valore e sviluppo del capitale sociale: la sfida per il sistema della pubblica amministrazione italiana, Rirea, Roma.

[14] Meneguzzo M. and Cepiku D. and Di Filippo E. 2006. Managerialità, innovazione e governance nella pubblica amministrazione, Aracne, Roma.

[15] Silcock, R. 2001. What is e-Government?, in Hansard Society for parliamentary Government, Parliamentary Affairs, $n^{\circ} 54$.

[16] Watson R.T. and Mundy B. 2001. A strategic perspective of electronic democracy, in Communication of the ACM, vol. 44, 1, January.

[17] Castelnovo W. and Simonetta M. 2005. Organizing e-Government for Small Local Government Organizations, report at The $5^{\text {th }}$ European Conference on e-Government, University of Antwerp, Belgium, 16 - 17 June 2005.

[18] Holmes, D. 2001. E-Gov, e-Business strategies for government, Nicholas Brealey Publishing, London.

[19] Zulfiqar K. and Shan P., 2001. Implementing e-Government Initiatives: An Exploratory Case Study, Pacis.

[20] Stiglitz J.E. and Orzag P.R. and Orzag J.M. 2000. The Role of Government in a Digital Age, Computer and Communications Industry Association, Washington DC.

[21] Devadoss P.R. and Pan S.L. and Huang J.C. 2002. Structurational Analysis of e-Government initiatives: a case study of SCO. Decision Support System, 34.

[22] Zulfiqar K.A. and Pan S.L. and Lee J. and Huang, J.C., 2001. e-Government: an Exploratory Study of On-line Electronic Procurement Systems, The $9^{\text {th }}$ European conference on Information Systems, Bled, Slovenia.

[23] Bombardelli, S. 2002. Informatica pubblica, e-government e sviluppo sostenibile, Rivista italiana di diritto pubblico comunitario, Giuffrè, Milano.

[24] Pollifroni, M. 2003. Processi e modelli di e-government ed e-governance applicati all'azienda pubblica, Giuffrè, Milano.

[25] United Nations Development Program, UN System Task Team on the Post 2015 UN Development Agenda, Governance and Development, New York, May, 2012

[26] Natalini, A. 2004. L'e-Government nell'ordinamento italiano, Vesperini G. (ed.), L'e-Government, Giuffrè, Milano.

[27] D'Elia, I. 2003. L'informatica e le banche dati, Cassese S. (ed.), Trattato di Diritto Amministrativo, Tomo II, Giuffrè, Milano.

[28] Freschi, A.C. 2002. Dall'e-Government verso l'e-Governance: considerazioni su diversi percorsi possibili, Conference Proceedings of L'attuazione dell'e-Government nel sistema regionale toscano, Firenze 13 gennaio 2002, available at www.retetoscana.it 
[29] Comite, U. 2011. L'evoluzione della governance nell'amministrazione pubblica: il ruolo delle Autorità indipendenti in una prospettiva economico-aziendale, in Luciani F., (ed.) 2011. Le Autorità Indipendenti come istituzioni pubbliche di garanzia, E.S.I., Napoli.

[30] Howard, M. 2001. E-Government Across the Globe: How Will "e" Change Government, in Government Finance Review, Vol. 17, n4.

[31] Layne K. and Lee J. 2001. Developing fully functional E-Government: A four-stage model, in Government Information Quarterly, n8.

[32] Chandler S. and Emanuels S. 2002. Transformation Not Automation, in Proceedings of the 2nd European Conference on e-Government, St Catherine's College Oxford, UK.

[33] United Nations - DPEPA (Division for Public Economics and Public Administration), 2002. Benchmarking eGovernment: A Global Perspective, http://pti.nw.dc.us/links/docs/ASPA UN egov survey.pdf.

[34] Irani Z. and Al-Sebie M. and Elliman T. 2006. Transaction Stage of e-Government Systems: Identification of its Location and Importance, Proceedings of the 39th Annual Hawaii International Conference on System Sciences (HICSS'06) Track 4.

[35] Bisio, L. and Mazzoleni, M. 2008. Manuale di management dell'ente locale, II Sole 24 Ore, Milano.

[36] Caruso G.D. and Catalfo P. 2002. L'uso di internet come strumento informativo - contabile negli eni locali territoriali italiani, Azienditalia, Vol. 9, fasc. 4, Ipsoa, Milano.

[37] Legge 6 agosto $2008 n^{\circ} 133$, Conversione in legge, con modificazioni, del decreto legge 25 Giugno 2008, n. 112, recante disposizioni urgenti per lo sviluppo economico, la semplificazione, la competitività, la stabilizzazione della finanza pubblica e la perequazione Tributaria, published in Gazzetta Ufficiale n. 195 del 21/08/2008 supplemento ordinario n. 196)

[38] Legge 31 dicembre 2009 n 196, Legge di contabilità e finanza pubblica, published in Gazzetta Ufficiale n. 303 del 31 dicembre 2009 - Supplemento ordinario n. 245

[39] Decreto legislativo 27 ottobre 2009 n¹50, Attuazione della legge 4 marzo 2009, $n$. 15, in materia di ottimizzazione della produttività del lavoro pubblico e di efficienza e trasparenza delle pubbliche amministrazioni, published in Gazzetta Ufficiale del 31 ottobre 2009, n. 254 - Supplemento Ordinario n. 197

[40] Decreto legislativo 7 marzo 2005 n82, Codice dell'Amministrazione Digitale, published in Gazzetta Ufficiale del 16 maggio 2005, n. 112 - Supplemento Ordinario n. 93

[41] Decreto Legislativo 30 dicembre 2010, $\mathrm{n}^{\circ} 235$, Modifiche ed integrazioni al decreto legislativo 7 marzo 2005, $n$. 82, recante Codice dell'amministrazione digitale, a norma dell'articolo 33 della legge 18 giugno 2009, n. 69, published in Gazzetta Ufficiale del 10 gennaio 2011, n. 6 - Supplemento Ordinario n. 8

[42] Borgonovi, E. 2006. Principi e sistemi aziendali per le amministrazioni pubbliche, Egea, Milano.

[43] Pitzalis, A. 2005., Le amministrazioni pubbliche e l'innovazione nelle tecnologie dellinformazione, Giuffrè, Milano.

\section{Author' biography:}

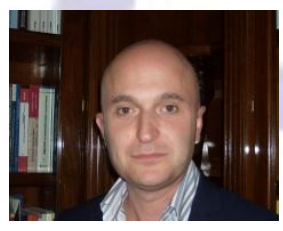

Prof. Ubaldo Comite was born in Cosenza, Italy, June 14 1971. He has a degree in Law (1994) and Economics (1996) at the University of Messina (Italy), and earned his Ph.D. in Public Administration at the University of Calabria, Rende (Cs) Italy, in 2005. Currently he is a professor of Budget and Business Organization at the Faculty of Economy, Department of Business Sciences, University of Calabria. His Research interests are: Private and Public Management, Non profit Organizations and Accounting. 